Article

\title{
Coastal Hazard Vulnerability Assessment Based on Geomorphic, Oceanographic and Demographic Parameters: The Case of the Peloponnese (Southern Greece)
}

\author{
Alexandra Tragaki, Christina Gallousi and Efthimios Karymbalis * (D) \\ Department of Geography, School of Environment, Geography and Applied Economics, Harokopio University, \\ 70 El. Venizelou Av., 17671 Kallithea, Athens, Greece; atragaki@hua.gr (A.T.); xgallousi@gmail.com (C.G.) \\ * Correspondence: karymbalis@hua.gr; Tel.: +30-210-9543159
}

Received: 5 April 2018; Accepted: 26 April 2018; Published: 1 May 2018

check for updates

\begin{abstract}
Today low-lying coastal areas around the world are threatened by climate change-related hazards. The identification of highly vulnerable coastal areas is of great importance for the development of coastal management plans. The purpose of this study is to assess the physical and social vulnerability of the Peloponnese (Greece) to coastal hazards. Two indices were estimated: The Coastal Vulnerability Index (CVI) and the Social Vulnerability Index (SVI). CVI allows six physical variablesto be related in a quantitative manner whilethe proposed SVI in this studycontains mainly demographic variables and was calculated for 73 coastal municipal communities. The results reveal that $17.2 \%$ of the shoreline $(254.8 \mathrm{~km})$ along the western and northwestern coast of the Peloponnese, as well as at the inner Messiniakos and Lakonikos Gulfs, is of high and very high physical vulnerability. High and very high social vulnerabilities characterize communities along the northwestern part of the study area, along the coasts of the Messinian and Cape Malea peninsulas, as well as at the western coast of Saronikos Gulf.
\end{abstract}

Keywords: sea-level rise; storm surge; physical vulnerability; social vulnerability; Peloponnese; Greece

\section{Introduction}

Coastal areas have always been attractive settling grounds for human populations. They constitute the transitional zone between land and the marine environment; a particular area with unique natural and socioeconomic characteristics thatencourage the concentration of human activities [1]. Land cover change is considered an important element of recent environmental change at a global level. The rate of land-cover alteration in the coastal regions is increasing dramatically worldwide due to the increasing and intensifying human use of the land. These changes have also been analyzed in semi-arid and dry Mediterranean areas, concentrating specificallyon the consequences of farmland abandonment and reforestation carried out at different scales [2]. The Mediterranean coastal zone has a history of a millennia of, more or less, intensive human use. During the last century, the population along the Mediterranean coasts has grown impressively. Changes in the coastal landscapes are mainly due to changes in human land use that in turn are the result of changes in the wider socio-economic environment. In the era of globalization, coastal rural space takes up new content due to the changes related to the fact that rural locales are no longer agricultural sites, as in the past [3]. Moreover, plenty of rural places in coastal zone have now become "peri-urban" areas. At the present moment, besides the regions surrounding the largest cities, population increase has slowed in the remaining areas. Demographic dynamics have highlighted the gap between populations living in urban centers as opposed to the surrounding rural areas. Since the 1980s, however, several Mediterranean cities have 
undergone a rapid transition from the traditional "compact growth" model to the more "dispersed" ones, characterized by huge expansions of the built up area around the core $[4,5]$. Following economic growth, the most recent challenge was a drastic low-density sprawl coupled with impressive deconcentration processes in inner coastal cities. The mobility of the urban population to coastal rural/peri-urban areas has brought to the fore new issues related to land use/land cover change and to the changing perceptions of rural place, of local needs, and of priorities for rural development [6]. These changes in land use and land cover increase the exposure of coastal communities to a range of natural hazards [7]. Hence today low-lying coastal areas around the world are threatened by climate change-related hazards, such as the accelerated global mean sea-level rise and extreme storm surge events [8-13].

Global mean sea-level rise is caused by an increase in the volume of the oceans. This in turn is caused by thermal expansion (due to the warming of the oceans), loss of ice by glaciers and ice sheets, and a reduction of liquid water storage on land [14]. Although the exact rates of present and future global mean sea-level rise due to global warming are uncertain, it is predicted to reach approximately $53-98 \mathrm{~cm}$ by the year 2100 [15]. The most adverse projections are reported by Pfeffer et al. [16], who project asea-level rise likely to reach $0.8 \mathrm{~m}$ to $2 \mathrm{~m}$. According to this study, the IPCC has not successfully modeled the dynamic development (decline) of the Greenland and Antarctic glaciers, a view also supported by other researchers (e.g., $[17,18])$.

Extreme storm surge events constitute an additional hazard. Storm surges, also referred to as meteorological residuals or meteorological tides, constitute along with the waves and the tidal oscillations the main components of extreme water levels along the coastal zone [9,19]. Storm surges are forced by wind driven water circulation towards or away from the coast and by atmospheric pressure driven changes of the water level; i.e., the inverse barometric effect. Some studies report an increased intensity and frequency of extreme water levels along several coastal regions in the world [20-23]. Hence the anticipated increase in extreme total water levels due to relative sea-level rise can be further enforced by an increase of the extreme storm surge level, which can exceed $30 \%$ of the relative sea-level rise [24].

Present sea-level trends in the Mediterranean basin have been estimated by analyzing available tide-gauge records longer than 35 years anda sea-level trend between 1.2 and $1.5 \pm 0.1 \mathrm{~mm} /$ year has been calculated for the longest records [25]. Decadal sea-level trends in the Mediterranean are not always consistent with global values. In particular, during the 1990s the Mediterranean has shown enhanced sea level rise of up to $5 \mathrm{~mm}$ /year compared to the global average (mostly attributed to higher warming). The sea-level trend for the period between 1944 and 1989, observed in Alexandria (Egypt), at the only long-term gauge station in the Eastern Mediterranean, is $1.9 \pm 0.2 \mathrm{~mm} /$ year and is the highest of the other stations in the basin [25]. According to the recent reports [15], mean sea-level in the Mediterranean is expected to rise at the rate of $5 \mathrm{~cm} /$ decade during the 21st century.

Regional projections of storm surge levels have been generated along the Mediterranean [26-28]. These projections show a general decreasing trend in the storminess of storm surge extremes in the Mediterranean Sea for a period of 150 years (1951-2100) under most of the considered climate change scenarios. This decreasing trend is mostly related to the frequency of local peaks and the duration and spatial coverage of the storm surges. However, the magnitudes of sea surface elevation extremes may increase in several Mediterranean sub-regions during the 21st century. There are clear distinctions in the contributions of winds and pressure fields to the sea-level height for various regions of the Mediterranean Sea, as well as on the seasonal variability of extreme values. The Aegean and Adriatic Seas are characteristic examples, where high surges are predicted to be mainly induced by low pressure systems and favorable winds, respectively [29].

Among the significant negative effects of the climate change-related coastal hazards are: coastal erosion with consequent loss of land of great economic, social, and environmental valueand infrastructure, frequent flooding of the low-lying coastal plains, inundation of ecologically significant wetlands, and threats to cultural and historical resources. Hence the identification of "sensitive" 
sections of coastline as well as the assessment of social vulnerability of the coastal communities is necessary for the development of coastal management plans. The understanding of a coastlines' response to both long-term and short-term sea-level rise as well as the assessment of the vulnerability of the coastal communities have become an important issue in recent years. Various approaches (mainly in the form of indices) have been proposed to predict the evolution of the coastal zone under the influence of sea-level rise. The relative physical vulnerability of different coastal environments to sea-level rise may be quantified by considering information regarding the important variables that contribute to coastal evolution in a given area, such as coastal geomorphology and slope, shoreline displacement, rate of relative sea-level change, tide range, wave height, and other related factors. Indices based mainly on these physical variables have been used to assess the physical vulnerability of coasts in the USA, Europe, Brazil, India, and Greece [30-37].

Recently, research on hazards in coastal areas has highlighted the need to incorporate other variable than physical variables in an attempt to capture the so-called social vulnerability [33,38-40]. Social vulnerability is described by various characteristics that condition a community's ability to respond to, cope with, recover from, and adapt to environmental hazards. According to a steadily growing literature, the socio-economic and demographic features are the main factors influencing social vulnerability [41]. In this context, investigations have been made relating to the evaluation of risk in coastal zones by taking into account not only natural but also socio-economic variables [39,42-45].

The aim of this study is to assess the overall vulnerability (physical and social) of the Peloponnese (southern Greek mainland) to both coastal erosion and flooding caused by climate change-related hazards. The assessment relies on the calculation of a Coastal Vulnerability Index (CVI) and a Social Vulnerability Index (SVI). The use of a quantitatively derived social vulnerability index, such as the proposed SVI, is important for two reasons. First, the method provides a useful tool for comparing the spatial variability in social vulnerability using a single value derived from multivariate characteristics. Second, SVI can be linked (statistically and spatially) to more physically based indices in calculating the overall vulnerability of a specific place. Not only does this index significantly contribute to the methods and metrics used in vulnerability science, but it also provides important comparative information for policy makers and emergency managers.

\section{Study Area}

The Peloponnese is a peninsula that covers an area of some $21,549.6 \mathrm{~km}^{2}$ and constitutes the southernmost part of mainland Greece (Figure 1). It is actually an island separated fromthe central part of the country by theGulf of Corinth, a restricted marine embayment, with a nearly $105 \mathrm{~km}$ longitudinal axis lying in the E-W direction. At the western end of the Gulf, the Peloponnese is connected to the mainland of Greece by the bridge of Rio-Antirio. To the east the Peloponnese is separated from the Greek mainland by the Corinth Canal (an artificially dredged channel, $8 \mathrm{~m}$ deep and $21 \mathrm{~m}$ wide) which links the Gulf of Corinth with the Saronikos Gulf. The study area has mountainous interior and deeply indented coasts, especially along its eastern coastline (Figure 1). It possesses four south-pointing peninsulas: the Messinian, the Mani, the Cape Malea, and the Argolid in the far northeast, which are separated by the NW-SE trending Gulfs of Messinakos, Lakonikos, and Argolikos.

The Peloponnese consists of 152 municipal communities (a municipal community is the lowest level of government within the organizational structure of Greece), 73 of which are coastal (Figure 1). It has a population of $1,047,000$, which corresponds to less than $10 \%$ of the total population of Greece. Most of its population is concentrated in the coastal zone. The average population density in the coastal municipal communities is 77.8 inhabitants $/ \mathrm{km}^{2}$, whereas the mean value for Greece is 82.29 inhabitants $/ \mathrm{km}^{2}$. Its GDP contributes less than $7 \%$ of total GDP in Greece. Unemployment rates are higher than the national rates and three times higher than the average unemployment rate in the EU-28. The economy of the study area is distributed between the primary sector (mostly agricultural activities) and tourism related servicesand a small yet gradually growing industrial activityover the last years. Despite the dominance of the mountainous terrain, the Peloponnese hosts 
some of the most fertile lands in the country, producing renowned wine labels and top quality olive oil. Tourism is the region's heavy industry with high quality services and infrastructure facilities mainly along the coastline. Nowadays, the infrastructure works in transportation create new challenges for the area. The national road that connects Athens with Patras (the capital of the Peloponnese and the third largest city in Greece), extends along the north shoreline of the Peloponnese, while numerous cities and settlements, such as Patras, Kalamata, Korinthos, Nafplio, etc., are coastal (Figure 1).

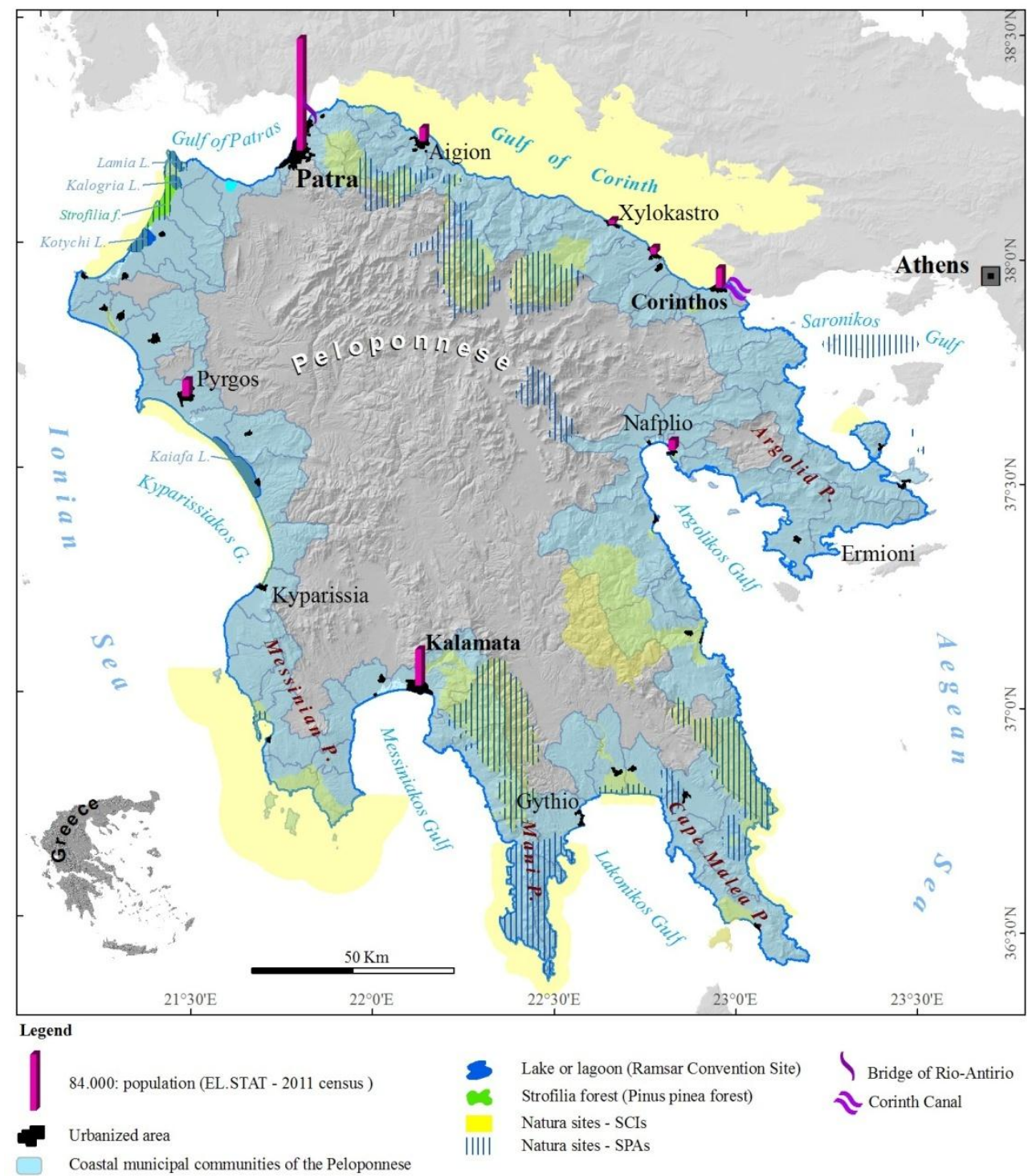

Figure 1. Hill-shaded map of the Peloponnese. The map also shows the 73 coastal municipal communities of the study area.

The Peloponnese is also of great environmental significance since it hosts ecologically important areas. Along its northwestern coast there is a $28 \mathrm{~km}$ zone with sandy beaches, dunes, lagoons (Kalogria, Strofilia, Lamia, and Kotychi, which is a Ramsar Convention site and the most significant lagoon in the Peloponnese), marshy areas, salt and freshwater wetlands, and the most extensive Pinuspinea forest in Greece (Strofilia forest) (Figure 1). Along the shore of the Kyparissiakos Gulf exists the significant wetland of Kaiafa Lake and a unique sand dune ecosystem of great ecological value.

From the above description it is more than evident that the Peloponnese deserves an assessment vulnerability study to spot regions of very high or high physical and social vulnerability, in order to promote relevant integrated management planning. 


\section{Materials and Methods}

\subsection{Physical Vulnerability}

For the assessment of the physical vulnerability of the Peloponnese to climate change-related coastal hazards we applied the index proposed by Thieler and Hammar-Klose [31], which modified the initial CVI [38]. The CVI allows six physical variables: coastal geomorphology, shoreline shifting rate, coastal slope, relative sea-level rise rate, mean wave height, and mean tidal range to be related in a quantitative manner. In each variable a relative risk value is assigned based on the potential magnitude of its contribution to the physical changes on the coast as sea-level rises. The variables are ranked from 1 to 5 according to Table 1, with rank 1 indicating very low vulnerability and rank 5 indicating very high vulnerability. The theoretical minimum and maximum values of the CVI are 0.4 and 51.0 respectively. The ranges of vulnerability ranking, used in this study, are those proposed for the coastal environment of Greece [36]. The CVI is calculated as the square root of the product of the six variables divided by their total number.

$$
\mathrm{CVI}=\sqrt{\frac{\mathrm{a} \cdot \mathrm{b} \cdot \mathrm{c} \cdot \mathrm{d} \cdot \mathrm{e} \cdot \mathrm{f}}{6}}
$$

where, a: geomorphology, b: shoreline erosion/accretion rate, c: coastal slope, d: relative sea-level rise rate, e: mean significant wave height and f: mean tide range.

Categorization of coastal geomorphology classes in this study (Table 1) was undertaken using recent ortho-rectified aerial photographs (taken in 2009). Since this variable also represents the bedrock outcropping along the shoreline, data for the rock types were interpreted from the geological maps of Greece (at 1:50,000 scale),published by the Greek Institute of Geology and Mineral Exploration (IGME).

Table 1. Ranges for vulnerability ranking of the six CVI variables. The ranges of vulnerability ranking, used in this study, are those proposed for the coastal environment of Greece [36].

\begin{tabular}{|c|c|c|c|c|c|}
\hline \multirow{2}{*}{ Variables } & \multicolumn{5}{|c|}{ Vulnerability Categories } \\
\hline & 1 & 2 & 3 & 4 & 5 \\
\hline Geomorphology & $\begin{array}{l}\text { Rocky, cliffed } \\
\text { coasts }\end{array}$ & $\begin{array}{l}\text { Medium cliffs, } \\
\text { indented coasts }\end{array}$ & $\begin{array}{c}\text { Low cliffs, } \\
\text { alluvial plains }\end{array}$ & $\begin{array}{l}\text { Cobble Beaches, } \\
\text { Lagoons }\end{array}$ & $\begin{array}{c}\text { Sandy beaches, } \\
\text { deltas }\end{array}$ \\
\hline $\begin{array}{c}\text { Shoreline Erosion }(-) / \\
\text { Accretion }(+) \text { rate }(\mathrm{m} / \text { year })\end{array}$ & $>(+1.5)$ & $(+1.5)-(+0.5)$ & $(+0.5)-(-0.5)$ & $(-0.5)-(-1.5)$ & $<(-1.5)$ \\
\hline Coastal Slope (\%) & $>12$ & $12-9$ & $9-6$ & $6-3$ & $<3$ \\
\hline $\begin{array}{l}\text { Relative Sea-Level rise } \\
\qquad(\mathrm{mm} / \text { year })\end{array}$ & $<1.8$ & $1.8-2.5$ & $2.5-3.0$ & $3.0-3.4$ & $>3.4$ \\
\hline Mean Wave Height (m) & $<0.3$ & $0.3-0.6$ & $0.6-0.9$ & $0.9-1.2$ & $>1.2$ \\
\hline Mean Tide Range (m) & $<0.2$ & $0.2-0.4$ & $0.4-0.6$ & $0.6-0.8$ & $>0.8$ \\
\hline Physical Vulnerability & very low & low & moderate & high & very high \\
\hline
\end{tabular}

Shoreline change rates were derived from ortho-rectified aerial photographs taken in 1969 and 2009, obtained from the Hellenic Military Geographical Service and the Hellenic Cadastre (Ktimatologio S.A.), respectively. The photomosaics of these photographs were manipulated within the GIS environment to digitize the shorelines of 1969 and 2009. The thematic layers of the 1969 and 2009 shorelines (in vector format) were overlaid, and with the use of GIS-based distance analysis functions, the final shoreline change map for the 40-year time period was obtained with estimated accretion and erosion rates.

To estimate the coastal slope values, a slope map of the coastal zone of the Peloponnese has been created with the use of the 1:5000 scale, topographic maps. With these maps as the main elevation source, the $5 \mathrm{~m}$ resolution Digital Elevation Model (DEM) of the coastal belt with an elevation from 0 to $50 \mathrm{~m}$ was created for the study area. Next, for this zone, the slope map was implemented within the ArcGIS spatial analysis extension environment, and a map of slope zones (according to Table 1) was constructed. Finally, for the assignment of the proper slope categorization to each coastline segment, an intersection of slope zones with the coastline was performed. 
The coast of the Peloponnese relative sea-level change is the sum of the eustatism component and the local long-term tectonic vertical land movements. Published information concerning the late Holocene relative sea-level trends at the broader area of the Peloponnese was considered [46].

Mean annual values of the significant wave height were abstracted from the "Wave and Wind Atlas of the Hellenic Seas" [47], which are based on offshore measurements for the period between 1999 and 2007 (POSEIDON program), whereas tidal range was deduced from published information [48]. Every section of the coastline was assigned a risk value based on each specific data variable and the CVI was calculated.

GIS software ArcGIS (ver. 10.2), provided the platform for the coastal mapping and the calculation of the CVI. For each variable, the entire coastline of the study area is segmented into five sensitivity classes, and a sensitivity rank number is assigned to each segment of the coast (indicating the vulnerability level in terms of the given variable). The method of computing the CVI in the present study is similar to that applied by Pendleton et al., [49] Thieller and Hammar-Klose [31] and Abuodha and Woodroffe [50]. The difference is that instead of the "raster" approach, input parameters and final CVI values were estimated in coastline segments.This modified approach seems appropriate for medium scale. The size of each segment was $50 \mathrm{~m}$. As mentioned above, for each of the six variables, a ranking on a scale of $1-5$ was assigned to each segment (with rank 1 representing very low vulnerability and rank 5 indicating very high vulnerability) following the classification scheme outlined in Table 1 . The final CVI map was generated by combining all of the variables. This map contains nearly 3500 segments of the coastline, each of which has a unique identity in its corresponding attribute table. Another column was added to this attribute table for the CVI formula so that the system generated the CVI values for all of the coastline segments of the Peloponnese. The combined CVI value was added as an attribute value for each coastline segment. Subsequently, the "natural breaks" classification method was used to categorize coastline segments according to their CVI magnitude for the construction of the final CVI zonation maps.

\subsection{Social Vulnerability}

Six variables have been used as indicators to assess social vulnerability of the coastal municipal communities of the Peloponnese: population density, share of women in total population, share of persons above 65 in total population, share of children below 5 in total population, share of foreign-born in total population, and share of low educated in total population. Demographic and socio-economic data were collected for all 1033 Greek municipal communities. Data were provided by the Hellenic Statistical Authority (EL.STAT) based on the 2011 Population and Household Census.

Since the six different variables used for the SVI calculation are measured in different units and scales, data must be standardized in order to be suitable for multivariate analysis and correlation tests. As most of the relevant data are not normally distributed, the method chosen is that of range standardization given by the following formula:

$$
\mathrm{x}_{\mathrm{A}, \mathrm{i}}^{\prime}=\frac{\mathrm{x}_{\mathrm{A}, \mathrm{i}}-\mathrm{x}_{\mathrm{A}, \min }}{\mathrm{x}_{\mathrm{A}, \max }-\mathrm{x}_{\mathrm{A}, \min }},
$$

where $x_{A, i}^{\prime}:$ the standardized value of the variable A referring to the municipal community $i, x_{A, i}$ : the observed value of the variable $A$ referring to the municipal community $i, x_{A, m i n}$ : the minimum observed value of the variable $\mathrm{A}$, and $\mathrm{x}_{\mathrm{A}, \max }$ : the maximum observed value of the variable $\mathrm{A}$.

All observation values are therefore between 0 (the case with the lowest value) and 1 (the case with the highest value). The six new standardized values were placed in an additive model to compose the SVI for each municipal community, making the assumption of an equal contribution of each variable to the community's overall vulnerability. The produced indicator is a relative measure of 
the overall vulnerability for each municipal community. The $\mathrm{SVI}_{i}$ for the municipal community $i$ is therefore given by the following formula:

$$
\mathrm{SVI}_{\mathrm{i}}=\sum_{\mathrm{A}=1}^{6} \mathrm{x}_{\mathrm{A}, \mathrm{i}}^{\prime}
$$

At a second stage, $\mathrm{SVI}_{\mathrm{i}}$ scores are classified based on standard deviations from the mean into five categories, ranging from less than $-1 \sigma$ on the lower end to more than $+1 \sigma$ on the upper end. Value 1 is given to the less vulnerable municipal communities while value 5 is given to the most vulnerable ones.

For each index (CVI and SVI) maps were produced depicting the geographic distribution of physical and social vulnerability along the coastal zone of the Peloponnese.

\section{Results and Discussion}

\subsection{Coastal Vulnerability Index}

The "coastal geomorphology" variable is non-numerical and expresses the relative response of different types of coastal landforms to sea-level rise. Geomorphology is ranked qualitatively according to the relative strength of the coastal landforms and rocks outcropping along the coast. The coastal zone of the Peloponnese is made up of a wide variety of features. The predominant coastal landform is steep marine cliffs made up of rocks highly resistant to coastal erosion, such as limestone and metamorphic rocks $(592.9 \mathrm{~km}-40.0 \%)$ followed by sandy and shingle beaches, located along the coastal alluvial plains and river deltas ( $343.2 \mathrm{~km}$, which is $23.2 \%$ of the coastline), cobble pocket beaches $(217.1 \mathrm{~km}-14.6 \%)$, medium rocky cliffs and indented coasts $(180.6 \mathrm{~km}-12.2 \%)$ and low rocky cliffs or cliffs made up of less resistant to erosion formations $(147.9 \mathrm{~km}-10 \%)$ (Table 2, Figure 2). Steep cliffs made up of hard geological formations (limestone and metamorphic rocks) offer maximum resistance and were classed with a rank of 1 , whereas medium rocky coastal cliffs and indented coasts or cliffs of medium slope made up of weaker formations were assigned sensitivity ranks of 2 and 3 , respectively. Cobble pocket beaches are susceptible to the effects of both natural marine processes and relative sea-level rise and are given a rank of 4 (high vulnerability). Sandy beaches, river deltas and fan-deltas were assigned a sensitivity rank of 5, while stabilized dune formations are considered that provide a kind of protection to the land behind them and were assigned a vulnerability rank of 4 (Table 2).

Table 2. The coastline length (as percentage \% of the total shoreline length) in each vulnerability category (1-5) for the physical variables (a-f) of the CVI.

\begin{tabular}{|c|c|c|c|c|c|c|}
\hline & \multirow[b]{2}{*}{ Variables } & \multicolumn{5}{|c|}{ Physical Vulnerability Classes } \\
\hline & & $\begin{array}{c}1 \\
\text { Very Low }\end{array}$ & $\begin{array}{c}2 \\
\text { Low }\end{array}$ & $\begin{array}{c}3 \\
\text { Moderate }\end{array}$ & $\begin{array}{c}4 \\
\text { High }\end{array}$ & $\begin{array}{c}5 \\
\text { Very High }\end{array}$ \\
\hline a. & Geomorphology & 40.0 & 12.2 & 10.0 & 14.6 & 23.2 \\
\hline b. & Shoreline Change & 0.2 & 2.8 & 91.2 & 5.3 & 0.5 \\
\hline c. & Coastal Slope & 55.5 & 8.3 & 7.9 & 14.1 & 14.3 \\
\hline d. & Relative Sea-level Rise & 0.0 & 100.0 & 0.0 & 0.0 & 0.0 \\
\hline e. & Significant Wave Height & 33.4 & 39.4 & 23.4 & 3.8 & 0.0 \\
\hline \multirow[t]{3}{*}{ f. } & Tidal Range & 100.0 & 0.0 & 0.0 & 0.0 & 0.0 \\
\hline & CVI values & $<1.2$ & $1.2-3.2$ & $3.2-5.2$ & $5.2-7.1$ & $>7.1$ \\
\hline & CVI (\%) & 46.5 & 18.7 & 17.5 & 12.0 & 5.2 \\
\hline
\end{tabular}

The shoreline change variable attempts to capture the historical trend of shoreline movement by determining the overall patterns of erosion or accretion. Shoreline change is one of the more complex parameters because the trend is typically variable over time [49]. The ranking of the shoreline change rate is based on the range of change in beach width values. A shoreline length of $1350.9 \mathrm{~km}$, which corresponds to $91.2 \%$ of the coastline, is relatively stable (mean shoreline shifting rate within 
$\pm 0.5 \mathrm{~m}$ /year), between 1969 and 2009. Nearly $78.2 \mathrm{~km}$ (5.3\%) of the coastline is retreating with a mean rate between -0.5 and $-1.5 \mathrm{~m}$ /year and a very small segment of the shoreline $(7.8 \mathrm{~km}-0.5 \%)$, which mainly consists of sandy beaches at the aprons of the Alfios and Evrotas River deltas, have undergone fast erosion (with rates $>-1.5 \mathrm{~m} /$ year). Nearly $41.5 \mathrm{~km}(2.8 \%)$ of the shoreline has been prograded with a mean accretion rate between +0.5 and +1.5 for the period between 1969 and 2009, while a very small percentage of the coastline $(0.2 \%-3.3 \mathrm{~km})$ is prograding faster with a mean accretion rate higher than $+1.5 \mathrm{~m}$ /year (Table 2). Accretion occurs at the mouth of some streams (Figure 2) due to increased sediment supply, especially during the rainy period of the year [51,52].

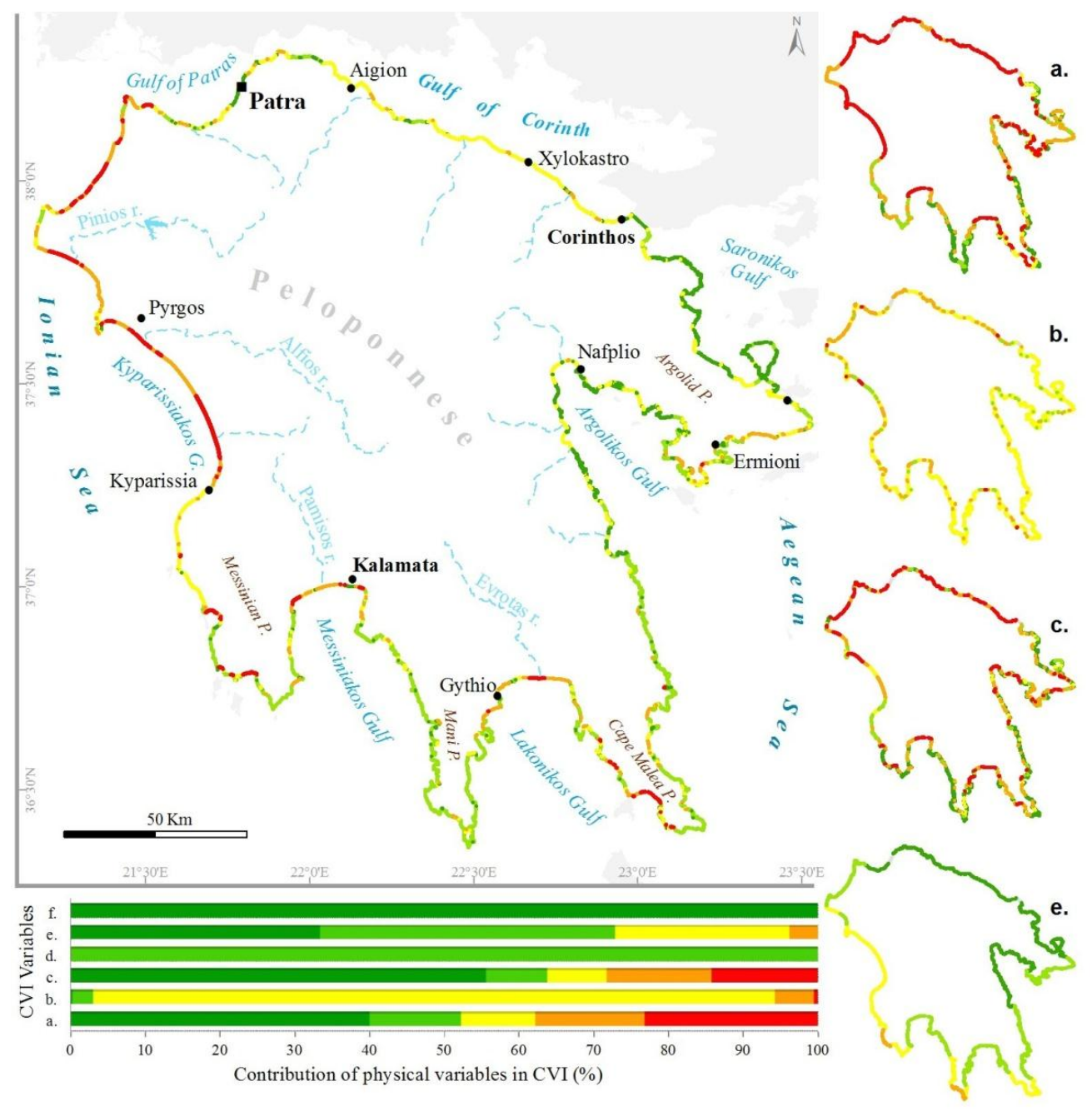

Figure 2. Maps of classification of the Peloponnese coastline into five physical vulnerability classes according to the variables of the Coastal Vulnerability Index (CVI) values. Inset maps (a-c,e) indicate the vulnerability ranking of various segments of the coast based on the CVI variables ((a) geomorphology, (b) shoreline change rate, (c) coastal slope and (e) mean significant wave height). Since the variables of relative sea-level rise and tidal range are considered to have the same value along the entire coastline of the Peloponnese, the figure does not include vulnerability ranking maps for these variables. The bar diagram shows the length (in percentage \%) of shoreline in each vulnerability category for the CVI variables.

Determination of the regional coastal slope identifies the relative sensitivity of inundation and the potential rapidity of shoreline retreat because low-sloping coastal regions are thought to retreat faster than steeper regions [51]. The ranges for vulnerability ranking of the coastal slope variable are the same as those used in similar studies from around the world [31,49]. Regions with coastal slopes 
lower than $3 \%$ were characterized with very high vulnerability, whereas coastal cliffs with slopes higher than $12 \%$ were classified as areas of very low vulnerability (Table 1). Nearly $56.0 \%$ of the coastal zone of the study area (which corresponds to $822.9 \mathrm{~km}$ ) belongs to the very low vulnerability class. Very low vulnerability area lies mainly along the western coast of the Saronikos Gulf as well as along the east and west coasts of the four NW-SE trending peninsulas: the Messinian, the Mani, the Cape Malea, and the Argolid. On the other hand,14.3\% of the study coastal zone (which corresponds to $211.4 \mathrm{~km}$ ) is low-lying and is characterized as very highly susceptible to inundation. This very highly vulnerable area lies partly along the southern coastline of the Gulf of Corinth as well as along part of the western coast of the Peloponneseand at the coast of the inner parts of the Messinakos, Lakonikos and Argolikos Gulfs (Figure 2). Low-lying coasts are occupied by beaches developed along the fronts of alluvial plains and river deltas. Nearly $14.0 \%$ of the coast $(208.4 \mathrm{~km})$ is comprisedof slope between 3 and $6 \%$ and is considered highly vulnerable, whereas $116.4 \mathrm{~km}(7.9 \%)$ of the coastal zone is of moderate vulnerability, having a slope between $6 \%$ and $9 \%$ (Table 2).

Due to the lack of recent accurate long-term sea-level measurements, the values for the variable of relative sea-level rise were estimated coupling the effects of eustatism and local land level movements caused by tectonics. The relative sea-level rise is considered to have the same value along the coastline of the Peloponnese (Table 2, Figure 2) and took a value $<2.0 \mathrm{~mm} /$ year based on estimations from studies relevant to eustatic sea-level rise in Greece [46]. This ranking is in agreement with the mean eustatic global sea-level rise rate for the time period between 1850 and 1950 [9], as well as with the trend of the sea-level for the period 1985-2001 at the station of Kalamata (0.6 $\pm 0.1 \mathrm{~mm} /$ year) [19].

Wave heights are proportional to the square root of wave energy, which is a measure of the capacity for erosion.The wave climate of the Peloponnese coastline is affected by offshore significant wave heights between 0.1 and $1.0 \mathrm{~m}$ [47], according to the output of the wave model (POSEIDON program), which has been calibrated with the use of offshore field measurements. A significant part of the coastline of the Gulf of Patras, as well as the entire coast of the Gulfs of Corinth and Argolikos is dominated by offshore significant wave heights $<0.3 \mathrm{~m}$. Thus, $494.8 \mathrm{~km}(33.4 \%)$ of the Peloponnese coastline is considered to have very low vulnerability (rank 1). Nearly $584.4 \mathrm{~km} \mathrm{(39.4 \% )} \mathrm{of} \mathrm{the} \mathrm{coastline,}$ located mainly along the northwestern and eastern shore of the Peloponnese, including also the coasts of Messiniakos and Lakonikos Gulfs, is characterized by offshore significant wave heights between 0.3 and $0.6 \mathrm{~m}$ (rank 2). Approximately $23.0 \%$ of the study area (which corresponds to $346.2 \mathrm{~km}$ ), that lies mostly along the western coast of the Peloponnese and partly the NW-SE facing coasts of the Messinian, the Mani, and the Cape Malea peninsulas are of moderate vulnerability since offshore wave heights range between 0.6 and $0.9 \mathrm{~m}$. Finally, small segments $(56.3 \mathrm{~km}-3.8 \%)$ of the southwestern shores of the Messinian and Mani peninsulas are dominated by significant wave heights between 0.9 and $1.2 \mathrm{~m}$ and are ranked as highly vulnerable (Figure 2e).

The tidal range is linked to both inundation and erosion hazards [30]. For the vulnerability ranking of the tidal range variable for the Peloponnese, the ranges proposed for Greece were considered (Table 1). These ranges were proposed taking into account the tide range variations for the Greek seas, which are generally less than $10 \mathrm{~cm}$ [48]. However, the overall fluctuation of sea-level exceeds $0.5 \mathrm{~m}$ due to meteorological forcing (differences in barometric pressure, wind, and wave setup) [53]. In this study, tidal range is ranked as such that extremely microtidal (tidal range $<0.2 \mathrm{~m}$ ) coasts are at low risk and less microtidal (tidal range $>0.8 \mathrm{~m}$ ) coasts are at high risk. The reasoning is that although a large tidal range dissipates wave energy, limiting beach or cliff erosion to a brief period of high tide, it also delineates a broad zone of intertidal area that will be most susceptible to inundation following long-term sea-level rise [30]. Furthermore, the velocity of tidal currents depends partially on the tidal range. High tidal range is associated with stronger tidal currents that are capable of eroding and transporting sediment [30]. The coast of the Peloponnese is a microtidal environment with tidal (astronomical) range $<4 \mathrm{~cm}$. As such, the tidal range variable is ranked with the value 1 (very low vulnerability) (Table 2, Figure 2). 
The CVI values alongside the Peloponnese range between 0.82 and 11.18. The median value of the index for the study area is 4.11 and the standard deviation is 2.17 . The geographical distribution of the vulnerability of the Peloponnese coast to climate change-related coastal hazards is presented schematically in Figure 2. CVI values above 7.1 are classified as having very high vulnerability. Nearly $77.6 \mathrm{~km}$, corresponding to $5.2 \%$ of the total coastline length, was assigned to this category. A total length of $177.2 \mathrm{~km}(12.0 \%)$ of the coastline is classified as having high vulnerability (CVI values between 5.2 and 7.1). The deltaic plains of the most extensive deltas (those of Alfios and Pinios Rivers) of the western Peloponnese as well as the coastal plains of the inner Messiniakos and Lakonikos Gulfs are characterized by very high and high levels of vulnerability, primarily due to the low regional coastal slope, the high erodible of the coastal landforms, the high rates of erosion and the relatively high offshore mean significant wave heights. About $17.5 \%(259.5 \mathrm{~km})$ of the shoreline, mainly along the Northern Peloponnese is moderately vulnerable (with CVI values between 3.2 and 5.2) while $18.7 \%(277.8 \mathrm{~km})$ is of low vulnerability (CVI values between 1.2 and 3.2). Finally, values below 1.2 are assigned to the very low vulnerability category with $46.5 \%(689.7 \mathrm{~km})$ of the shoreline belonging to this class (Table 2). The low and very low vulnerability categories are primarily located at the western rocky coasts of the Peloponnese, as well as along the NW-SE oriented cliffy coasts of the Messinian, Mani, and Cape Malea peninsulas (Figure 2).

\subsection{Social Vulnerability Index (SVI)}

Densely populated areas are thought to be more vulnerable, as the total amount of people and assets per $\mathrm{km}^{2}$ poses a higher vulnerability of total damage in case of a disaster. Additionally, high population density increases the evacuation time as well as the consequences of a disaster (injuries and fatalities). In our case-study, population density ranges from 5.8 to 1352.7 inhabitants $/ \mathrm{km}^{2}$ with a mean score of 109.9 (standard deviation: 196.99). In respect to this criterion, 25 municipal communities (which correspond to $34.2 \%$ of the 73 total communities) are classified as low vulnerable, whereas the other 48 communities belong to the moderate vulnerability class (Table 3). Higher population densities are concentrated primarily along the southern coast of the Gulf of Corinth and at the western part of the Peloponnese (Figure 3a).

Table 3. Number of coastal communities (as percentage $\%$ of the total coastal municipal communities of the Peloponnese) in each vulnerability category (1-5) for the social variables (a-f) of the SVI.

\begin{tabular}{|c|c|c|c|c|c|c|}
\hline & \multirow[b]{2}{*}{ Variables } & \multicolumn{5}{|c|}{ Social Vulnerability Classes } \\
\hline & & $\begin{array}{c}1 \\
\text { Very Low }\end{array}$ & $\begin{array}{c}2 \\
\text { Low }\end{array}$ & $\begin{array}{c}3 \\
\text { Moderate }\end{array}$ & $\begin{array}{c}4 \\
\text { High }\end{array}$ & $\begin{array}{c}5 \\
\text { Very High }\end{array}$ \\
\hline a. & Population Density & 0.0 & 34.2 & 65.8 & 0.0 & 0.0 \\
\hline b. & Share of Women in t.p. & 16.4 & 5.5 & 65.8 & 12.3 & 0.0 \\
\hline c. & Share of Persons above 65 in t.p. & 13.7 & 26.0 & 50.7 & 5.5 & 4.1 \\
\hline d. & Share of Children below 5 in t.p. & 4.1 & 11.0 & 57.5 & 16.4 & 11.0 \\
\hline e. & Share of foreign-born in t.p. & 0.0 & 8.2 & 39.7 & 17.8 & 34.2 \\
\hline f. & Share of Low Educated in t.p. & 8.2 & 31.5 & 45.2 & 4.1 & 11.0 \\
\hline & Number of Communities & 8 & 15 & 22 & 14 & 14 \\
\hline SVI & $(\%)$ & 11.0 & 20.5 & 30.1 & 19.2 & 19.2 \\
\hline
\end{tabular}

Women, especially those living in less developed economies or in low status households, have limited access to knowledge and resources and are therefore less efficient in protecting or helping themselves out of a disaster [54]. Their care-giving role is an additional aggravating factor. Thus, relevant literature considers high shares of women in a population a high risk factor. In our case-study, the share of women in the total population ranges from $28.9 \%$ to $51.6 \%$, with amean value of $48.9 \%$ (standard deviation: 0.028 ). Most of the communities (48 out of 73 ) are moderately vulnerable, 16 municipal communities (21.9\%) belong to the very low and low vulnerability classes, while $9(12.3 \%)$ of them are highly vulnerable (Table 3 and Figure $3 b$ ). 
Elders, especially those living alone, often have mobility limitations and special needs that may require the assistance of others. Hence high values of "share of persons above 65 in total population" indicate high vulnerability. The shares of elders within the communities populations range from $10.7 \%$ to $38.9 \%$, with a mean score of $23.55 \%$ (standard deviation: 0.058 ). Most of the communities (37 corresponding to $50.7 \%$ ) fall into the moderate vulnerability category, whereas 29 (39.7\%) show low and very low vulnerabilities (Table 3). Regarding this particular variable, four highly and three very highly vulnerable coastal communities are located in the southern part of the Peloponnese (Figure 3c).

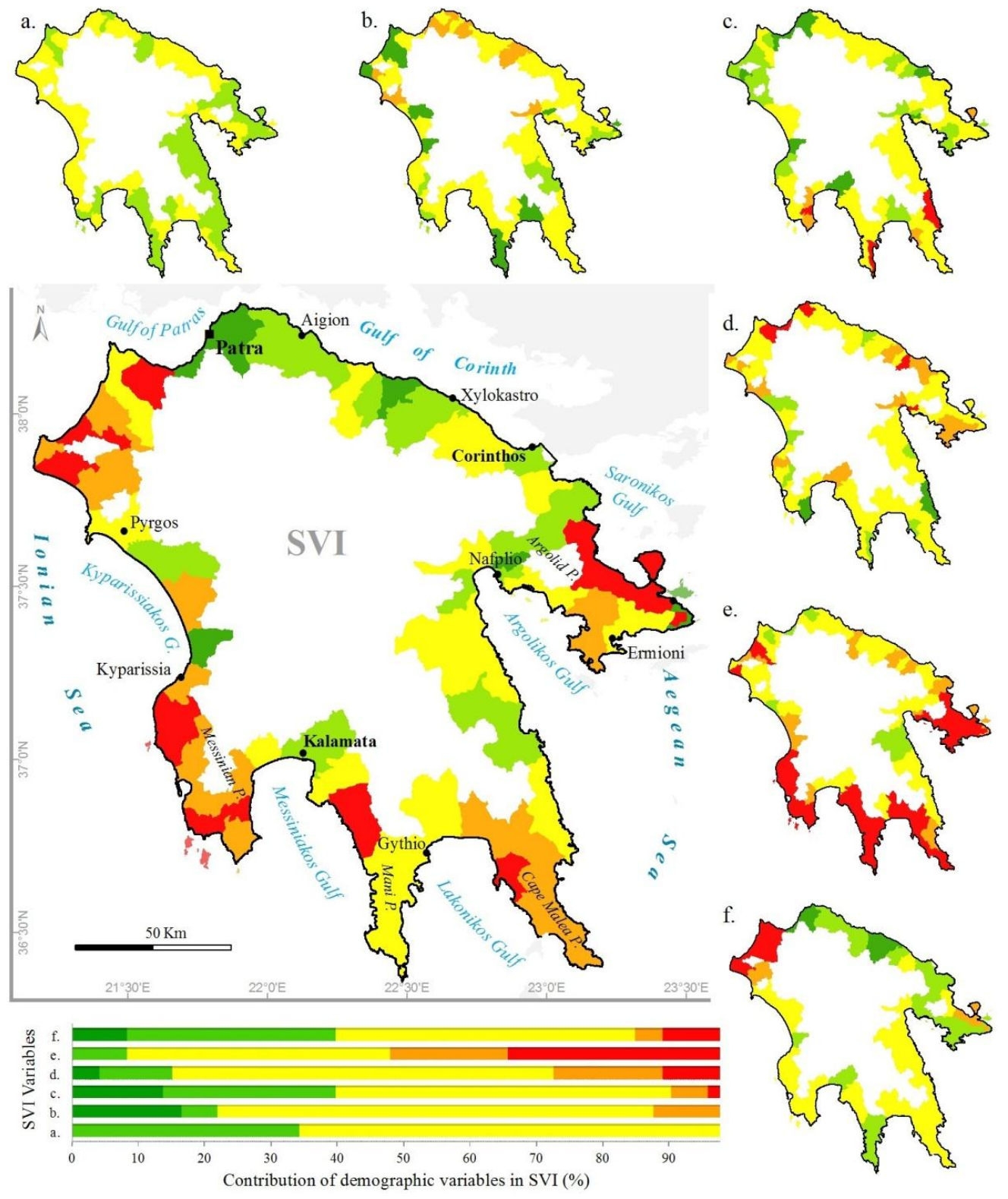

Figure 3. Maps of classification of the coastal municipal communities of the Peloponnese into five social vulnerability classes according to the variables of the Social Vulnerability Index (SVI) values. Inset maps (a-f) indicate the social vulnerability ranking of the communities based on the categorization of the SVI variables' values ((a) population density, (b) share of women in total population, (c) share of persons above 65 in total population, (d) share of children below 5 in total population, (e) share of foreign-born in total population and (f) share of low educated in total population). Inset bar diagram show the length (in percentage \%) of shoreline in each vulnerability category for the SVI variables. 
Children ( $<5$ years) can hardly protect themselves during a disaster for they lack the necessary resources, knowledge, as well as life experience to survive. The values of the variable "share of children below 5 in total population" range between $2.9 \%$ and $9.8 \%$, with a mean score of $5.34 \%$ (standard deviation: 0.057). Vulnerability increases with the values of this parameter. The majority of the coastal municipal communities (42-57.5\%) show moderate vulnerability, 20 out of $73(27.4 \%)$, primarily located at the north and northwest part of the Peloponnese, belong to the high and very high vulnerability classes, while the rest show low and very low vulnerabilities (Table 3, Figure 3d).

Racial and ethnic minorities are supposed to be more vulnerable to hazards for they are more likely to be poor [55]. Since we lack detailed ethnic data at this administrative level, we usethe "share of foreign-born in total population". Non-natives are thought to be more vulnerable for different reasons: (i) disaster communication is made more difficult due to limited language skills (ii) the impact may be greater due to higher social and economic marginalization as well as to cultural differences. Across the coastal municipalities of Peloponnese, the shares of foreignersrange from $2.9 \%$ to $35.1 \%$ of total population with mean score of $11.8 \%$ (standard deviation: 0.057). A significant number of communities (38 out of 73-52\%), especially those of the Argolid, Cape Malea, Mani, and Messinian peninsulas are characterized by high and very high vulnerability (Figure 3e). A concentration of highly and very highly vulnerable communities is also observed at the northwestern part of the Peloponnese.

"Share of low educated in total population" is a variable that reflects the socio-economic status of an area. Low education implies limited access to information, followed by poor prevention measures and is often related to social and economic deprivation. The share of low-educated within the municipalities populationgoes from a minimum value of $9.5 \%$ to a maximum of $21.6 \%$ with mean score of $14.9 \%$ (standard deviation: 0.033 ). In respect to this demographic feature, most of the coastal municipal communities of the Peloponnese belong to the moderate, low, and very low vulnerability categories (Table 3). The geographic distribution of this parameter shows the presence of highly and very highly vulnerable communities at the northwestern part of the study area. Some communities along the southwestern shores of Saronikos Gulf are also of high vulnerability (Figure 3f).

In order to compose the SVI and due to the different scales of measures used for each variable, the values have been standardized [56]. The SVI ranges from a minimum value of 0.91 (lowest social vulnerability) to 2.67 (highest social vulnerability) with a mean score of 2.11 (standard deviation: 0.25 ). The geographical distribution of the social vulnerability to climate change-related coastal hazards for the Peloponnese is presented schematically in Figure 3. Most communities exhibit low or moderate levels of social vulnerablity since more than 6 out of 10 communities are classified in the first three groups. However, the share of highly and very highly vulnerable communities goes up to almost $38.4 \%$ (Table 3). High and very high levels of social vulnerability are clustered in communities along the coasts of the Messinian and Cape Malea peninsulas, as well as along the western coast of Saronikos Gulf and at the northwestern part of the Peloponnese. In contrast, the communities along the southern coast of the Gulf of Corinth, and most of the communities along the east coast of the Gulf of Patras, as well as most of the Argolikos Gulf coastal communities to the east, have moderate to very low social vulnerability levels (Figure 3).

The comparison among the final two CVI and SVI maps shows that seven coastal municipal communities of the Peloponnese (Vouprasia, Lechena, Vartholomio, Gastouni, Amaliada, Zacharo, and Elos) show high and very high levels of overall (both physical and social) vulnerability to costal hazards. The high overall vulnerability of these communities is a function of high or very high values of SVI while more than $80 \%$ of their coastal zone is also of high and very high physical vulnerability. The highly vulnerable (physically and socially) communities are concentrated at the northwestern coastal zone of the Peloponnese, while there is one highly vulnerable community at the inner part of the Lakonikos Gulf (Figure 4). 


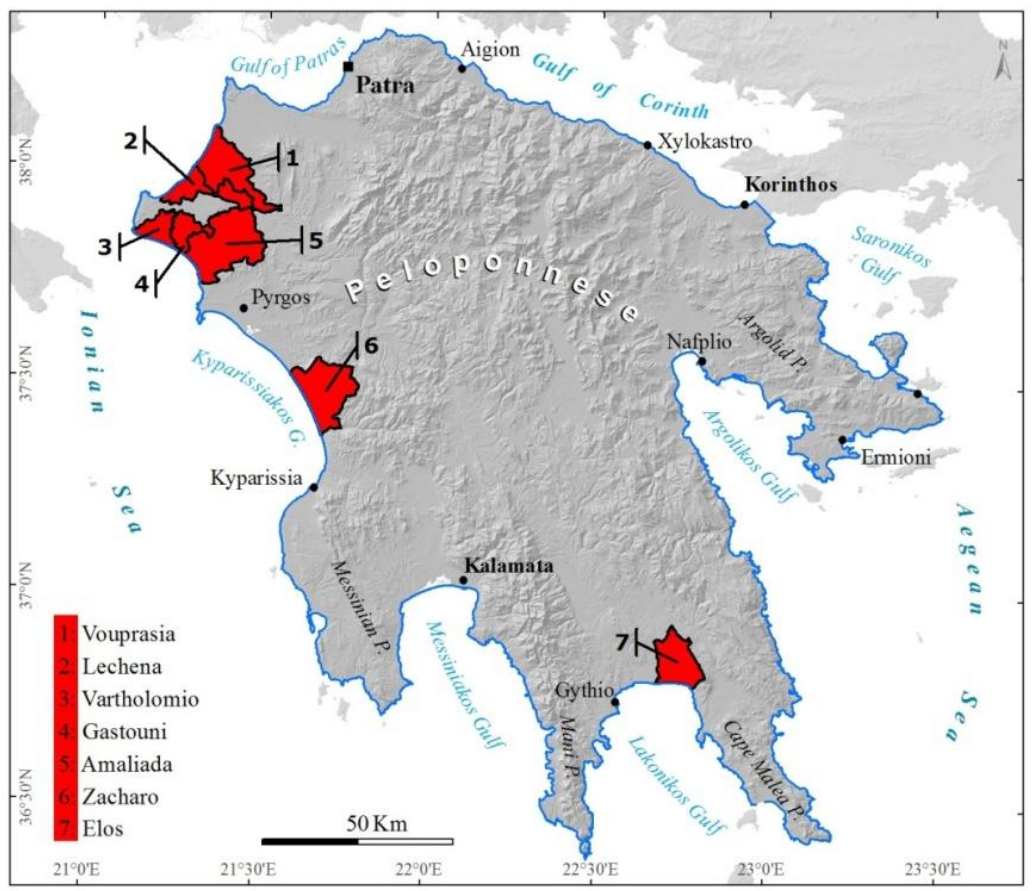

Figure 4. Location map of the seven more vulnerable (both physically and socially) municipal communities of the Peloponnese. These municipal communities have high or very high values of SVI while more than $80 \%$ of their coastal zone is also of high and very high physical vulnerability.

\section{Conclusions}

Of the six physical vulnerability variables, "geomorphology", "regional coastal slope", and "mean significant wave height" introduce the greatest variability to the CVI values. Among the other three parameters, "shoreline change rate" shows a small variation, while "tidal range" and "relative sea-level rise rate" have the same values along the entire coastline. On the other hand, all six variables used as indicators to assess social vulnerability, show a great variability. Among the social vulnerability variables,"share of foreign-born in total population", "share of children below 5 in total population" and "share of low educated in total population" are those that increase the SVI values within the study area.

The application of the proposed methodology reveals that there are differences among the geographical distribution of physical and social vulnerability. Nearly $17.2 \%$ of the shoreline $(254.8 \mathrm{~km})$ consisting primarily of low-lying sandy beaches and deltaic plains, has high and very high levels of physical vulnerability. Coastline segments of high physical vulnerability level are geographically concentrated at the western and northwestern coast of the Peloponnese, as well as at the inner coastal areas of Messiniakos, and the Lakonikos Gulfs. The highly and very highly social vulnerable communities are concentrated along the northwestern coast of the Peloponnese, along the coasts of the Messinian and Cape Malea peninsulas, as well as at the western coast of Saronikos Gulf. There are seven high risk coastal municipal communities in the study area (Vouprasia, Lechena, Vartholomio, Gastouni, Amaliada, Zacharo and Elos) andthey present high and very high values of social vulnerability. Accordingly, more than $80 \%$ of their coastal zone is also of high and very high physical vulnerability. Six of them are located in the northwestern Peloponnese and host ecologically important sites.

This study provided a comprehensive and detailed spatial GIS digital database of topographic, geological, and physio-geographical characteristicsfor $1481.7 \mathrm{~km}$ of shoreline, as well as population and demographic data for the coastal municipal communities of the Peloponnese, which can be renewed and expanded further to incorporate newly available data (e.g., storm surge, socio-economic status, 
land values), including new variables (e.g., sediment budget, environmental parameters) in the future for better results of physical and social vulnerability assessment.

The implementation of the indices used in this study, at the national scale could assist in a preliminary identification of the hazardous and vulnerable coastal areas of the country. CVI and SVI can be also integrated and used in the policies defined by Agenda 2030 for Sustainable Development, which is a plan of action for the people, the planet and for prosperity that also seeks to strengthen universal peace and freedom. The main target of Goal 13 is to take urgent action to combat climate change and its impacts. After the initial assessment of the most physically vulnerable segments of the coastlines to coastal hazards, focusing on regions with specific socio-economic and environmental interest is required, in order to re-examine the study area on a larger, more detailed, scale. The results of the categorization of the coasts in different risk categories can be a useful tool for managers of coastal areas and for those responsible for carrying out national protection policies, strategies and planning of the coastal zone against climate change driven natural hazards. Hence the application of CVI and SVI along the Greek coast would strengthen resilience and adaptive capacity to climate-related hazards and coastal natural disasters in the country.

Author Contributions: A.T. analyzed the demographic data and developed the Social Vulnerability Index; C.G. created and organized the GIS spatial database and created the maps of the geographic distribution of the vulnerability variables (physical and social); E.K. analyzed the data regarding the Coastal Vulnerability Index; A.T, C.G. and E.K. wrote the paper.

Acknowledgments: We would like to thank G.B. and H.S., Guest Editors of this Special Issue, for their helpful suggestions as well as the anonymous reviewers for their comments and corrections that significantly improved the paper.

Conflicts of Interest: The authors declare no conflict of interest.

\section{References}

1. Costanza, R. The ecological, economic, and social importance of the oceans. Ecol. Econ. 1999, 31, 199-213. [CrossRef]

2. Bellot, J.; Bonet, A.; Pena, J.; Sánchez, J. Human impacts on land cover and water balances in a Coastal Mediterranean county. Environ. Manag. 2007, 39, 412-422. [CrossRef] [PubMed]

3. Chalkias, C.; Papadopoulos, A.; Ouils, A.; Karymbalis, E.; Detsis, V. Land cover changes in the coastal peri-urban zone of Corinth, Greece. In Proceedings of the Tenth International Conference on the Mediterranean Coastal Environment, Rhodes, Greece, 25-29 October 2011; Volume 2, pp. 913-923.

4. Salvati, L.; Munafò, M.; Morelli, V.G.; Sabbi, A. Lowdensitysettlementsand land use changes in a Mediterranean urban region. Landsc. Urban Plan. 2012, 105, 43-52. [CrossRef]

5. Catalán, B.; Saurí, D.; Serra, P. Urban sprawl in the Mediterranean? Patterns of growth and change in the Barcelona metropolitan region 1993-2000. Landsc. Urban Plan. 2008, 85, 174-184. [CrossRef]

6. Romano, B.; Zullo, F. The urban transformation of Italy's Adriatic Coast Strip: Fifty years of unsustainability. Land Use Policy 2014, 38, 26-36. [CrossRef]

7. Satta, A.; Puddu, M.; Venturini, S.; Giupponi, C. Assessment of coastal risks to climate change related impacts at the regional scale: The case of the Mediterranean region. Int. J. Disaster Risk Reduct. 2017, 24, 284-296. [CrossRef]

8. Church, J.; White, N. Sea-level rise from the late 19th to the early 21st century. Surv. Geophys. 2011, 32, 585-602. [CrossRef]

9. Losada, I.J.; Reguero, B.G.; Méndez, F.J.; Castanedo, S.; Abascal, A.J.; Mínguez, R. Long-term changes in sea-level components in Latin America and the Caribbean. Glob. Planet. Chang. 2013, 104, 34-50. [CrossRef]

10. Hinkel, J.; Lincke, D.; Vafeidis, A.T.; Perrette, M.; Nicholls, R.J.; Tol, R.S.J.; Marzeion, B.; Fettweis, X.; Ionescu, C.; Levermann, A. Coastal flood damage and adaptation costs under 21st century sea-level rise. Proc. Natl. Acad. Sci. USA 2014, 111, 3292-3297. [CrossRef] [PubMed]

11. Hogarth, P. Preliminary analysis of acceleration of sea level rise through the twentieth century using extended tide gauge data sets (August 2014). J. Geophys. Res. Oceans 2014, 119, 7645-7659. [CrossRef]

12. Hoggart, S.P.G.; Hanley, M.E.; Parker, D.J.; Simmonds, D.J.; Bilton, D.T.; Filipova-Marinova, M.; Franklin, E.L.; Kotsev, I.; Penning-Rowsell, E.C.; Rundle, S.D.; et al. The consequences of doing nothing: The effects of seawater flooding on coastal zones. Coast. Eng. 2014, 87, 169-182. [CrossRef] 
13. Jevrejeva, S.; Moore, J.C.; Grinsted, A.; Matthews, A.P.; Spada, G. Trends and acceleration in global and regional sea levels since 1807. Glob. Planet. Chang. 2014, 113, 11-22. [CrossRef]

14. Allen, J.C.; Komar, P.D. Climate controls on US west coast erosion processes. J. Coast. Res. 2006, 22, 511-529. [CrossRef]

15. IPCC. Summary for policy makers. In Climate Change 2013: The Physical Science Basis; Stocker, T.F., Qin, D., Plattner, G.K., Tigno, M., Allen, S.K., Boschung, J., Nauels, A., Xia, Y., Bex, V., Midgley, P.M., Eds.; Cambridge University Press: Cambridge, UK, 2013.

16. Pfeffer, W.T.; Harperand, J.T.; O'Neel, S. Kinematic constraints on Glacier Contributions to 21st Century Sea-Level Rise. Science 2008, 321, 1340-1343. [CrossRef] [PubMed]

17. Rohling, E.J.; Grant, K.; Bolshaw, M.; Roberts, A.P.; Siddall, M.; Hemleben, C.H.; Kucera, M. Antarctic temperature and global sea-level closely coupled over the past five glacial cycles. Nat. Geosci. 2009, 2, 500-504. [CrossRef]

18. Grinsted, A.; Moore, J.C.; Jevrejeva, S. Reconstructing sea-level from paleo and projected temperatures 200 to 2100 AD. Clim.Dyn. 2010, 34, 461-472. [CrossRef]

19. Lowe, J.A.; Woodworth, P.L.; Knutson, T.; McDonald, R.E.; McInnes, K.L.; Woth, K.; von Storch, H.; Wolf, J.; Swail, V.; Bernier, N.B.; et al. Past and Future Changes in Extreme Sea Levels and Waves. Understanding Sea-Level Rise and Variability; Wiley-Blackwell: London, UK, 2010.

20. Ullmann, A.; Monbaliu, J. Changes in atmospheric circulation over the North Atlantic and sea-surge variations along the Belgian coast during the twentieth century. Int. J. Climatol. 2010, 30, 558-568. [CrossRef]

21. Izaguirre, C.; Méndez, F.J.; Espejo, A.; Losada, I.J.; Reguero, B.G. Extreme wave climate changes in Central-South America. Clim. Chang. 2013, 119, 277-290. [CrossRef]

22. Wang, X.L.; Feng, Y.; Swail, V.R. Changes in global ocean wave heights as projected using multimodel CMIP5 simulations. Geophys. Res. Lett. 2014, 41, 1026-1034. [CrossRef]

23. Weisse, R.; Bellafiore, D.; Menéndez, M.; Méndez, F.; Nicholls, R.J.; Umgiesser, G.; Willems, P. Changing extreme sea levels along European coasts. Coast. Eng. 2014, 87, 4-14. [CrossRef]

24. Vousdoukas, M.; Voukouvalas, E.; Annunziato, A.; Giardino, A.; Feyen, L. Projections of extreme storm surge levels along Europe. Clim. Dyn. 2016, 47, 3171-3190. [CrossRef]

25. Marcos, M.; Tsimplis, M.N. Coastal sea-level trends in Southern Europe. Geophys. J. Int. 2008, 175, 70-82. [CrossRef]

26. Marcos, M.; Jordà, G.; Gomis, D.; Pérez, B. Changes in storm surges in southern Europe from a regional model under climate change scenarios. Glob. Planet. Chang. 2011, 77, 116-128. [CrossRef]

27. Jordà, G.; Gomis, D.; Álvarez-Fanjul, E.; Somot, S. Atmospheric contribution to Mediterranean and nearby Atlantic sea level variability under different climate change scenarios. Glob. Planet. Chang. 2012, 80-81, 198-214. [CrossRef]

28. Conte, D.; Lionello, P. Characteristics of large positive and negative surges in the Mediterranean Sea and their attenuation in future climate scenarios. Glob. Planet. Chang. 2013, 111, 159-173. [CrossRef]

29. Androulidakis, Y.; Kombiadou, K.; Makris, C.; Baltikas, V.; Krestenitis, Y. Storm surges in the Mediterranean Sea: Variability and trends under future climatic conditions. Dyn. Atmos. Oceans 2015, 71, 56-82. [CrossRef]

30. Gornitz, V. Global coastal hazards from future sea-level rise. Glob.Planet. Chang. 1991, 89, 379-398. [CrossRef]

31. Thieler, E.R.; Hammar-Klose, E.S. National Assessment of Coastal Vulnerability to Sea-Level Rise; U.S. Atlantic Coast; U.S. Geological Survey: Reston, VA, USA, 1999.

32. Pendleton, E.A.; Thieler, E.R.; Williams, S.J. Coastal Vulnerability Assessment of Cape Hatteras National Seashore (CAHA) to Sea-Level Rise; USGS Open File Report; US Geological Society: Reston, VA, USA, 2008.

33. Diez, P.G.; Perillo, G.M.E.; Piccolo, C.M. Vulnerability to sea-level rise on the coast of the Buenos Aires Province. J. Coast. Res. 2007, 23, 19-126. [CrossRef]

34. Rao, K.N.; Subraelu, P.; Rao, T.V.; Malini, B.H.; Ratheesh, R.; Bhattacharya, S.; Rajawat, A.S. Sea-level rise and coastal vulnerability: An assessment of Andhra Pradesh coast, India through remote sensing and GIS. J. Coast. Conserv. 2008, 12, 195-207. [CrossRef]

35. Gaki-Papanastassiou, K.; Karymbalis, E.; Poulos, S.; Seni, A.; Zouva, C. Coastal vulnerability assessment to sea-level rise based on geomorphological and oceanographical parameters: The case of Argolikos Gulf, Peloponnese, Greece. Hell. J. Geosci. 2011, 45, 109-121. 
36. Karymbalis, E.; Chalkias, C.; Chalkias, G.; Grigoropoulou, E.; Manthos, G.; Ferentinou, M. Assessment of the sensitivity of the southern coast of the Gulf of Corinth (Peloponnese, Greece) to sea-level rise. Cent. Eur. J. Geosci. 2012, 4, 561-577. [CrossRef]

37. Karymbalis, E.; Chalkias, C.; Ferentinou, M.; Chalkias, G.; Magklara, M. Assessment of the Sensitivity of Salamina and Elafonissos islands to Sea-level Rise. J. Coast. Res. 2014, 70, 378-384. [CrossRef]

38. Gornitz, V.; Daniels, R.C.; White, T.W.; Birdwell, K.R. The development of a coastal vulnerability assessment database: Vulnerability to sea-level rise in the U.S. southeast. J. Coast. Res. 1994, 12, 327-338.

39. Boruff, B.; Emrich, C.; Cutter, S.L. Erosion hazard vulnerability of US coastal countries. J. Coast. Res. 2005, 21, 932-942. [CrossRef]

40. Lichter, M.; Felsenstein, D. Assessing the costs of sea-level rise and extreme flooding at the local level: A GIS-based approach. Ocean Coast. Manag. 2012, 59, 47-62. [CrossRef]

41. Flanagan, B.E.; Gregory, E.W.; Hallisey, E.J.; Heitgerd, J.L.; Lewis, B. A Social Vulnerability Index for Disaster Management. J. Homel. Secur. Emerg. Manag. 2011, 8. [CrossRef]

42. Szlafsztein, C.; Sterr, H. A GIS-based vulnerability assessment of coastal natural hazards, state of Pará, Brazil. J. Coast. Conserv. 2007, 11, 53-66. [CrossRef]

43. Gorokhovich, Y.; Leiserowitz, A.; Dugan, D. Integrating Coastal Vulnerability and Community-Based Subsistence Resource Mapping in Northwest Alaska. J. Coast. Res. 2014, 30, 158-169. [CrossRef]

44. Satta, A.; Puddu, M.; Firth, J.; Lafitte, A. Climate Risk Management Tools: Towards a Multi-Scale Coastal Risk Index for the Mediterranean; Plan Bleu Report; Plan Bleu: Valbonne, France, 2015.

45. Mavromatidi, A.; Briche, E.; Claeys, C. Mapping and analyzing socio-environmentalvulnerability to coastal hazards induced by climate change: An application to coastal Mediterranean cities in France. Cities 2018, 72, 189-200. [CrossRef]

46. Lambeck, K. Sea-level change and shore-line evolution in Aegean Greece since Upper Palaeolithic time. Antiquity 1996, 70, 588-611. [CrossRef]

47. Soukisian, T.; Hatzinaki, M.; Korres, G.; Papadopoulos, A.; Kallos, G.; Anadranistakis, E. Wave and Wind Atlas of the Hellenic Seas; Hellenic Centre for Marine Research Publication: Anavyssos, Greece, 2007.

48. Tsimplis, M.N. Tidal oscillations in the Aegean and Ionian Seas. Estuar. Coast. Shelf Sci. 1994, 39, $201-208$. [CrossRef]

49. Pendleton, E.A.; Thieler, E.R.; Williams, S.J. Importance of coastal change variables in determining vulnerability to sea- and lake-level change. J. Coast. Res. 2010, 26, 176-183. [CrossRef]

50. Abuodha, P.A.O.; Woodroffe, C.D. Assessing vulnerability to sea-level rise using a coastal sensitivity index: A case study from southeast Australia. J. Coast. Conserv. 2010, 14, 189-205. [CrossRef]

51. Dwarakish, G.S.; Vinay, S.A.; Natesan, U.; Asano, T.; Kakinuma, T.; Venkataramana, K.; Jagedeesha, B.; Badita, M.K. Coastal vulnerability assessment of the future sea-level rise in Udupi coastal zone of Karnataka state, west coast of India. Ocean Coast. Manag. 2009, 52, 467-478. [CrossRef]

52. Parcharidis, I.; Kourkouli, P.; Karymbalis, E.; Foumelis, M.; Karathanassi, V. Time Series Synthetic Aperture Radar Interferometry for Ground Deformation Monitoring over a Small Scale Tectonically Active Deltaic Environment (Mornos, Central Greece). J. Coast. Res. 2013, 29, 325-338. [CrossRef]

53. Alexandrakis, G.; Karditsa, A.; Poulos, S.; Ghionis, G.; Kampanis, N.A. Vulnerability assessment for to erosion of the coastal zone to a potential sea-level rise: The case of the Aegean Hellenic coast. In Environmental Systems in Encyclopedia of Life Support Systems (EOLSS); Sydow, A., Ed.; Eolss Publisher: Oxford, UK, 2009.

54. Enarson, E.; Morrow, B.H. A gendered perspective: The voices of women. In Hurricane Andrew: Ethnicity, Gender, and the Sociology of Disasters; Peacock, W.G., Morrow, B.H., Gladwin, H., Eds.; International Hurricane Center, Laboratory for Social and Behavioral Research: Miami, FL, USA, 1997; pp. 116-140.

55. Rygel, L.; O'Sullivan, D.; Yarnal, B. A method for constructing a Social Vulnerability Index: An application to hurricane storm surges in a developed country. Mitig. Adapt. Strateg. Glob. Chang. 2006, 11, 741-764. [CrossRef]

56. Cutter, S.L.; Mitchell, J.T.; Scott, M.S. Revealing the vulnerability of people and places: A case study of Georgetown county, South Carolina. Ann. Assoc. Am. Geogr. 2000, 90, 713-737. [CrossRef]

(C) 2018 by the authors. Licensee MDPI, Basel, Switzerland. This article is an open access article distributed under the terms and conditions of the Creative Commons Attribution (CC BY) license (http:/ / creativecommons.org/licenses/by/4.0/). 